were allowing foreign-owned companies to control access to seeds.

Selborne said at the end of the meeting that it had not been designed to reach agreement on the issues discussed. $\mathrm{He}$ nonetheless drew several personal conclusions, which will be submitted to Blair as the prime minister prepares for the G8 summit.

One of these will urge governments "to ensure that there is an acceptable balance between public and private research funding for biosafety applications".

A separate report on the Bangkok meeting is due to be presented to the G8 summit by OECD officials. The OECD was asked for guidance at the G8 meeting in Cologne two years ago, and helped to organize last week's conference and a similar meeting held jointly with the British government in Edinburgh last year (see Nature 404,$112 ; 2000$ ) to help to formulate its response.

One proposal that emerged from Edinburgh - the creation of an international panel to study the scientific basis of concern over the safety of GM crops - was rejected by the G8 nations in the face of opposition from the United States.

British officials hope that a more limited set of proposals will win the endorsement of the G8 countries and thus help to prevent differences between Europe and the United States from developing into a full-blown trade conflict.

\title{
Millennium Dome sees signs of a Wellcome break
}

\section{Peter Aldhous, London}

London's Millennium Dome could be transformed from a national embarrassment into a leading centre for biomedical research.

The Wellcome Trust, the world's largest medical research charity, has reportedly earmarked $\mathfrak{E} 300$ million (US\$420 million) for a bid to convert the riverside site into laboratories and an exhibition space featuring the trust's work.

The trust would not comment on the reports, which first appeared in The Sunday Telegraph, but issued a statement saying that its "investment portfolio is constantly under review and at any one time several opportunities may be under consideration".

The Dome was conceived as the centrepiece of Britain's millennium celebrations, its huge tent-like structure housing a series of exhibits illustrating contemporary life. It cost more than $\mathfrak{E} 600$ million, but attracted only about half of its projected 12 million visitors during its year-long opening. The whole site now lies empty, costing the government $\mathfrak{k} 1$ million per month to maintain.

Buying the Dome is well within the financial reach of the Wellcome Trust, which has assets of some $\mathfrak{E} 15$ billion. The $\mathfrak{E} 300$ million is reported to cover both the costs of purchasing the site and building laboratory facilities.
The Wellcome Trust has previously invested large sums in research facilities, most notably to build the Sanger Centre at Hinxton near Cambridge, responsible for sequencing one-third of the human genome.

But the trust has been frustrated by the denial of planning permission for a $\mathfrak{E} 100$ million extension at Hinxton to provide space for spin-off biotechnology companies (see Nature 400, 803; 1999). The trust says it still intends to pursue a revised application.

There is a shortage of laboratory space in the British capital, as highlighted by a group called the London Biotechnology Network, which said last month that up to 40 new biotech companies will need more than 5,000 square metres of lab space within the next two years.

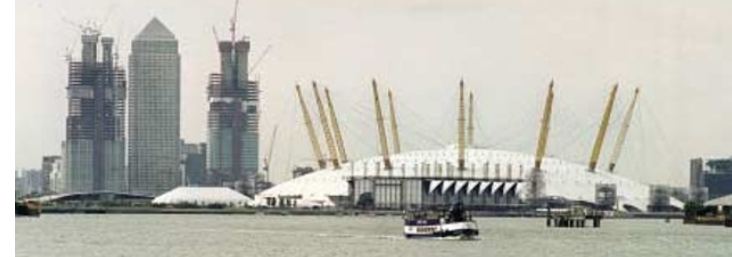

Sales pitch: will Wellcome buy London's Dome?

\section{Simple technology could reclaim America's lost votes}

Mark Schrope, Washington

Pencil, paper and simple optical scanners are the most reliable proven technologies for avoiding another voting fiasco akin to last November's US presidential election, say some of the country's leading scientists.

David Baltimore, president of the California Institute of Technology, and Charles Vest, president of the Massachusetts Institute of Technology in Cambridge, jointly launched the Caltech-MIT Voting Technology Project a few weeks after the election.

The project's findings - issued on 16 July - are that high-technology solutions have a poor record in improving voting accuracy, and that authorities should abandon them. The report, Voting: What Is, What Could Be, says that paper ballots and optical scanners are the most accurate, with an error rate of around $1.5 \%$, whereas punch-card machines and electronic devices register nearly twice as many errors.

The report points out that Internet voting and other advanced solutions could open the door to large-scale, systematic voter fraud in the United States. It argues, nonetheless, that "properly developed" hightechnology options could eventually prove superior to what is currently available.

The widely publicized problems that dogged last year's vote in Florida, where George W. Bush beat Al Gore by a tiny margin, were rampant throughout the country, the project finds.

"The problem is more serious than we had imagined even last December," says Baltimore. "The voting process has simply not been taken seriously as a central element of the democratic process."

The group estimates that between 4 million and 6 million votes were lost because of ballot, registration and other problems. To slash that number by about 1.5 million in the next election, the project recommends abandoning existing electronic, punch-card and mechanical-lever systems in favour of hand counting and optical scanning of hand-marked ballots. It also calls for a new system for field-testing other alternatives.

According to the report, procedural changes such as making regional registration information available at polling sites could prevent the loss of another 2 million or so votes, but further reductions will require better voting technology.

It recommends federal funding to develop new voting technologies which could include ballots, either electronic or paper, that can be printed on-site, allow voters to confirm their selections, and be stored for later review. Although opticalscanner systems come closest to that, they have drawbacks, including high costs, inflexibility and significant scanning inaccuracy.

"We want every American's vote to count," says Vest. To that end, he says, the next phase of the project will focus on the design of new equipment and processes. "Computer technology appropriately applied offers significant opportunity for cost-effective advances," he says.

http://www.vote.caltech.edu 